\title{
The impact of starting process on wear of cylinder wall
}

The results of experimental research of cylinder wall wearing process were presented in this article. Researches were conducted on the basis of four strokes spark ignition one cylinder engine. The main goal of presented research was assessment of impact of cold start condition on intensity of cylinder wall wearing process. The new one and worn engine oil with grade $10 \mathrm{~W} 40$ was used for experimental research. The experimental research was conducted on specially developed experimental stand. The wear of cylinder wall was assessed on the basis of cylinder diameter and wall roughness measurements.

Key words: cylinder wall, oil grade, wear

\section{INTRODUCTION}

The strain of engine's construction due to the gaseous forces, inertia forces and the temperature's gradients on the wall of combustion chamber are transferred to the crankshaft system. Among the parts of combustion engine which have a significant influence on energy losses and on the friction forces are piston, piston's rings and cylinder wall (TPC). It results on mechanical efficiency on the level of $45 \div 65 \%$. Moreover, $75 \%$ of friction forces loses are results of piston rings and $25 \%$ of these are connected with friction between the piston and cylinder wall [7]. So the crankshaftpiston system is given to extremal thermic and mechanical strains. For decrease in friction loses it is necessary to obtain a good lubrication conditions between cylinder wall, piston and piston's rings. The modern engines with high output power and its trend to minimize of engine piston displacement (downsizing) are strongly given to thermic and mechanical strains. Engine cooling system and lubrication system are responsible for an optimal regulation of engine work conditions. As the cooling water is used for indirect thermal energy transfer to the air, the oil used in lubrication system directly flows through the zones where the friction appears. So the engine lubrication system have to lubricate the friction areas and have to transfer the thermal energy similar to the indirect cooling system $[1,2]$.

\section{Engine start}

The character of the engine's work conditions (especially the TPC system) are the one of the main of loses reasons for an engine. During the piston's move from TDC to BDC and non-stability of piston velocity with its stops have a negative impact on oil film achievement connected to the cylinder wall [7]. Moreover, it is impossible to obtain a regular distribution of stress made by piston's rings due to the cylinder shape changes and the friction wear of cylinder wall, especially during "cold" starts and very high engine load [9].

Due to the wedge-shaped zone from TPS system which appears during the engine work the oil film between on cylinder wall have been obtained. Thickness of oil film on cylinder wall isn't symmetric in cooperation to pressure resulted from piston ring. When the piston starts, the piston rings are changing its position and shape - what results in micro rings deformation and stress in oil film. These mechanical relation have an impact on pressure resulted from piston rings and oil film thickness.

Among the forces in TPC system can be indicated axial and radial direction forces [6]. The different values of engine crankshaft rotations disturb an oil film on cylinder wall. Significant influence in building of wedge-shaped oil film on cylinder wall have shape of piston rings.

Oil film between piston rings and cylinder wall have a hydrodynamic and elastic-hydrodynamic reactions. The hydrodynamic reactions results in piston rings and cylinder wall separating and lubrication.

Hydro-dynamic influence of oil film can be observed between piston rings and cylinder wall (Fig. 1), especially for TDC and BDC, when piston velocity decrease to zero. In these time the conditions for oil film generation have been done due to the transverse piston rings movement. It results in the worse of lubrication conditions [8].

As shows the results presented by Włodarski, the biggest cylinder wall wear appeared close to the TDC. Elastic and hydrodynamic reactions of cooperated friction parts results in resilience micro-deformation and changes in oil film thickness and pressure [7].

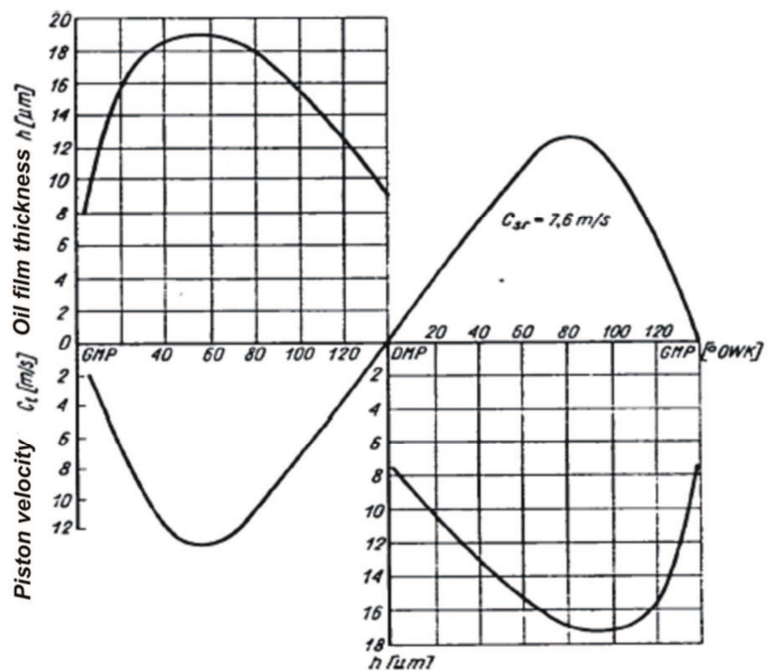

Fig. 1. The minimal oil film thickness by piston ring-cylinder wall system and the crankshaft position [8] 
The mechanism of separation piston rings and cylinder wall was presented in Fig. 2. When the engine makes an intake stroke the oil ring has a contact with the fresh oil film $\left(\mathrm{h}_{\mathrm{ol}}\right)$ and wiper and compression rings are moving on the rest of oil film $\left(\mathrm{h}_{\mathrm{wz}}\right)$ and is a residue oil which leaved the oil ring. During the compression stroke there is a reverse process.

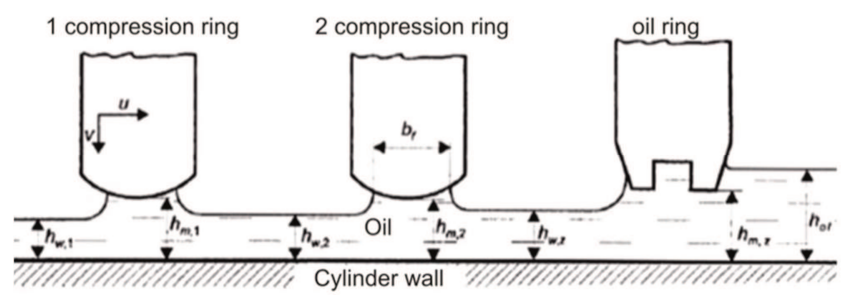

Fig. 2. The scheme of relation between the piston rings and cylinder wall [6]

Lubrication process of cylinder wall is created by oil splash and by the movement of piston ring during engine work. The oil pumping process is caused by the ring end movement for first stroke and start the engine, oil isn't pumped to combustion chamber. Moreover, the film created by cold oil on cylinder wall is quite unevenness. It have an impact on increase in wear of TPC system. Resistance forces depends mainly from a static friction coefficient and it is connected with the time calculated from the last engine start. The sources of these effect are decay of oil film and increase in micro adhesion between cooperated parts. The experiments conducted by Janecki and Gołąbek [5] indicates that 100 times of cold starting for engine (for diesel engine) is an equivalent of 200 hours of work.

The momentum of resistance during a starting process is mainly caused by forces of kinematic friction. This resistance covers from 70 up to $90 \%$ of total friction momentum for TPC system, as well in the main bearings of crankshaft and camshaft system. The momentum of kinematic friction resistance during a starting process depends from the construction factors, assembly parameters and form the temperature of oil in lubrication system.

For the first part of starting process, on cylinder wall can't be achieve a minimal thickness of oil film. It caused of increase in friction forces and wear of cooperated engine parts. Furthermore, there can appear a dry friction phase. When the engine starts, between parts of TPC system can be achieve wear process caused by adhesion forces, friction forces and corrosion. This situation was presented in Fig. 3.

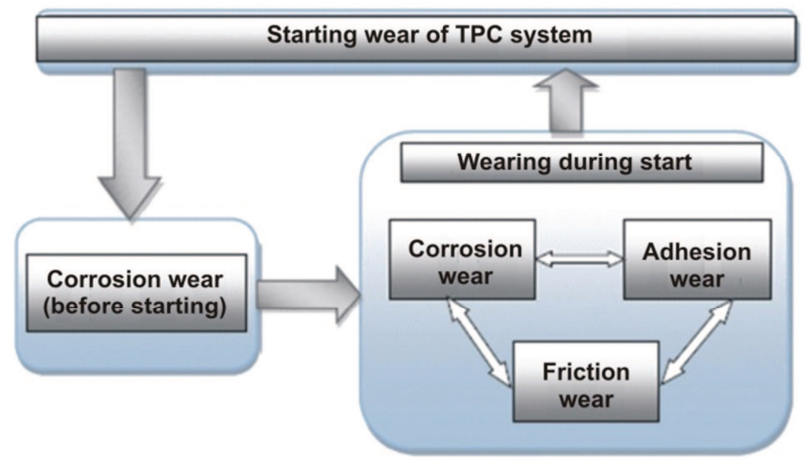

Fig. 3. The scheme of starting wear of TPC system [3]
The adhesion between TPC parts is caused by a broke micro-connection surfaces which worked for initial time of engine starting process.

One of the main factor which significantly results in a cylinder's wall friction wear during starting process is time gap where the engine didn't run. When this gap grow up, there can be observed increase in wear caused by electro-chemical corrosion and by gravity-flow of oil from cylinder wall to oil sump.

Temperature of the engine is also an important factor, which results in wear of TPC system. When the engine temperature grows an intensity of cylinder wall wear declines. It was presented in Fig. 4. For the engine cold start (temperature about $0^{\circ} \mathrm{C}$ ) the intensity of cylinder's wall wear is an equivalent of 80 kilometers, for the lower temperature for ex. $-10^{\circ} \mathrm{C}-100$ kilometers.

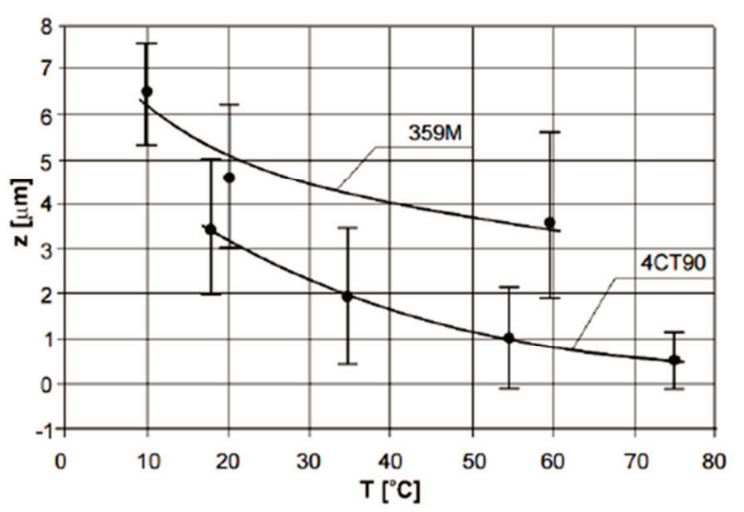

Fig. 4. The average cylinder wall wear (with standard error) for the diesel engine type 4CT90 and 359M dependence on temperature (T) after 1000 engine starts [4]

On the basis of literature's data we can write that engine starting process cause about $15 \%$ to $75 \%$ of total engine wear [3].

\section{Experimental stand}

Researches were conducted on the basis of specially developed experimental stand, where can mentioned:

- four strokes, one cylinder SI engine,

- electric engine with drive belt system,

- steering system,

- engine temperature measurement system,

- air temperature measurement system.

Table1. Technical data of engine 139QMA [10]

\begin{tabular}{|l|c|}
\hline Parameter & Type/value \\
\hline Starting system & manual/electric starter \\
\hline Engine type & 4 strokes \\
\hline No. cylinder & 1 \\
\hline The type of combustion chamber & Hemispheric \\
\hline Cam system & Valve type, OHC, chain drive \\
\hline $\begin{array}{l}\text { Cylinder bore x piston stroke } \\
{[\mathrm{mm}]}\end{array}$ & $39.0 \times 41.4$ \\
\hline Power [kW/min $\left.{ }^{-1}\right]$ & $2,2 / 7500$ \\
\hline Torque [Nm/min $\left.{ }^{-1}\right]$ & $2,9 / 7000$ \\
\hline Compression ratio & $\begin{array}{l}\text { Pressure-splash system with } \\
\text { internally toothed pump and } \\
\text { reticulated oil filter }\end{array}$ \\
\hline Lubrication system & \\
\hline
\end{tabular}


The engine type 139QMA used for experiment was taken from motorcycle Baotian BT4QT. View of experimental stand was presented in Fig. 5 and the technical date was presented in Table.

The combustion engine was started by electric starter which was steered by electric time control system. Time of starting and time gap between next start were determined by operator. It lets us obtain very similar condition for engine cold start.

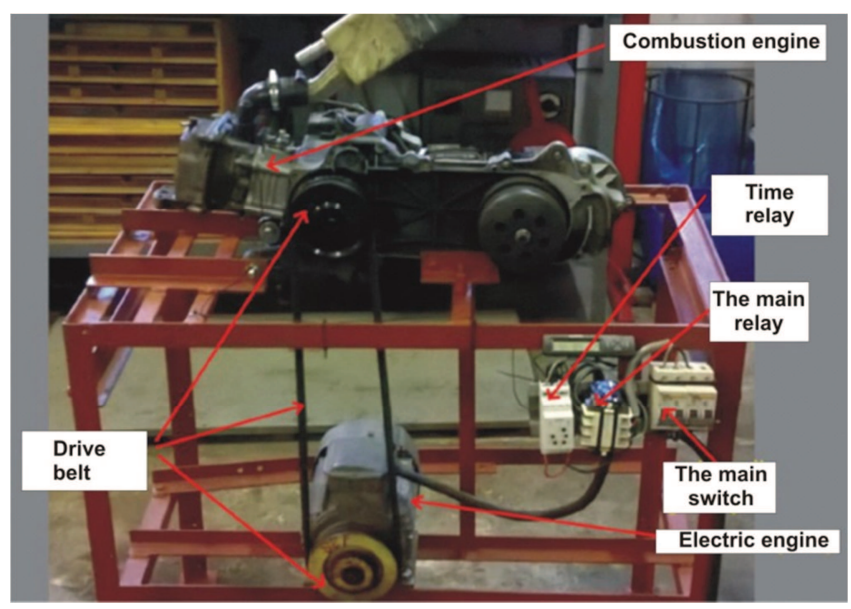

Fig. 5. The view of experimental stand with combustion engine and electric steering system

\subsection{Experimental results}

For conducting of research two set of nominal cylinder with piston and piston ring were used. The third nominal cylinder was assessed as a basis and it was presented in Fig. 7. In relation to nominal parts dimension (cylinder no. 3) the wear of two others were calculated.

Total time of starting process was 100 hours for each cylinder (with the new piston and piston rings) set. It was determined by steering system as:

- single starting time $-3 \mathrm{~s}$,

- break between next starting $-15 \mathrm{~s}$,

- number of starting cycles -27000 .

The scheme of experimental processing was presented in Fig. 6.

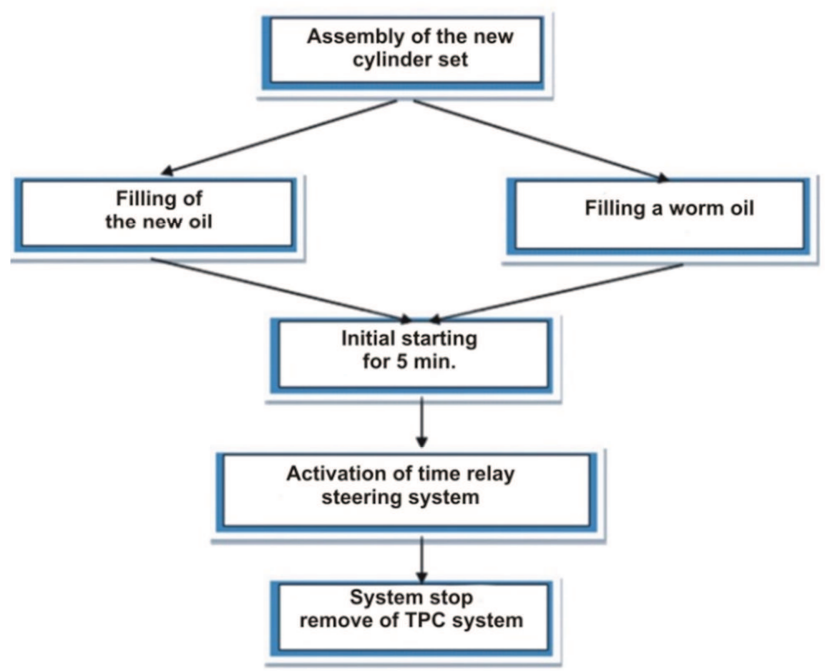

Fig. 6. The scheme of experiment processing
The air temperature in laboratory during conducted researches was about $18.5^{\circ} \mathrm{C} \pm 1^{\circ} \mathrm{C}$ with a relative humidity $61 \% \pm 5 \%$.

Cylinder wearing was measured by increase its diameter. Other goal of conducted research was assessment of influence of oil grade on wearing process. For theses research the new oil (Mobil Super ${ }^{\mathrm{TM}}$ 2000) and worn-out oil with grade $10 \mathrm{~W} 40$ was used. The worn-out oil was used after 1500 hours of engine work with nominal load. For the future research:

- basic cylinder was indicated as no. 1,

- cylinder worked with the new oil - no. 2,

- cylinder worked with worn oil - no. 3 .

For accuracy of wear measurements a TRIMOS VERTICAL AUTOMATIC TVD 800A altimeter was used. The equipment of this device let us make some length measurements and shape deformation and localization error as well. The technical parameters of this device was presented in Table 2

Table 2. Altimeter TRIMOS VERTICAL AUTOMATIC TVD 800A technical data [11]

\begin{tabular}{|l|c|}
\hline \multicolumn{1}{|c|}{ Parameter } & Value \\
\hline Total scope $[\mathrm{mm}]$ & 805 \\
\hline $\begin{array}{l}\text { Scope without changing of measurement } \\
\text { equipment }[\mathrm{mm}]\end{array}$ & 525 \\
\hline Total offset of metrological handle $[\mathrm{mm}]$ & 240 \\
\hline Length measurement accuracy $[\mu \mathrm{m}]$ & 5 \\
\hline Measurement pressure $[\mathrm{g}]$ & 300 \\
\hline Total device height $[\mathrm{mm}]$ & 845 \\
\hline
\end{tabular}

Cylinder diameter measurements were conducted for three planes:

- below of TDC,

- up of BDC,

- in the middle of piston stroke,

and for two perpendicular direction. Localisation of measurement points were presented in Fig. 7.

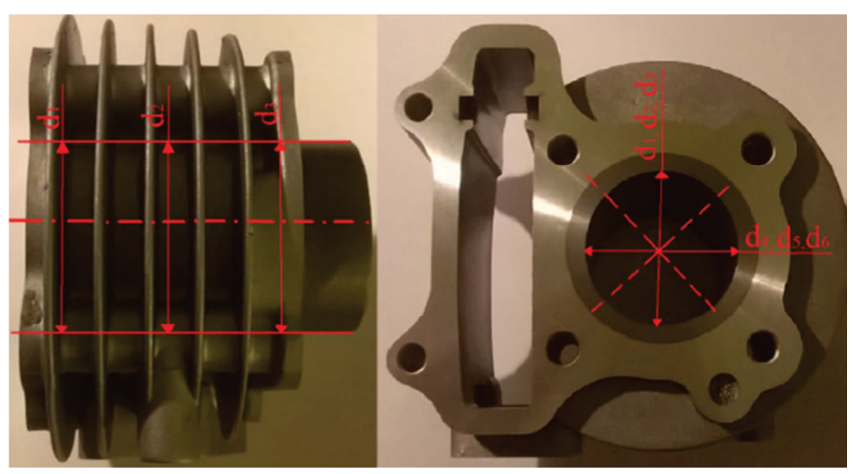

Fig. 7. Localization of measurement points for cylinders

Each measurement was repeated three time and on the basis of this arithmetic mean was calculated. The results of measurement and calculation were presented in Table 3 and diameter's differences in Table 4. 
Table 3. Results of cylinder diameter measurement (arithmetic mean)

\begin{tabular}{|l|l|l|l|l|l|}
\hline \multicolumn{5}{|c|}{ Cylinder no. 1 } \\
\hline $\mathrm{d}_{1}[\mathrm{~mm}]$ & 39.011 & $\mathrm{~d}_{2}[\mathrm{~mm}]$ & 39.011 & $\mathrm{~d}_{3}[\mathrm{~mm}]$ & 39.010 \\
\hline $\mathrm{d}_{4}[\mathrm{~mm}]$ & 39.010 & $\mathrm{~d}_{5}[\mathrm{~mm}]$ & 39.011 & $\mathrm{~d}_{6}[\mathrm{~mm}]$ & 39.010 \\
\hline \multicolumn{6}{|c|}{ Cylinder no.2 } \\
\hline $\mathrm{d}_{1}[\mathrm{~mm}]$ & 39.014 & $\mathrm{~d}_{2}[\mathrm{~mm}]$ & 39.012 & $\mathrm{~d}_{3}[\mathrm{~mm}]$ & 39.012 \\
\hline $\mathrm{d}_{4}[\mathrm{~mm}]$ & 39.015 & $\mathrm{~d}_{5}[\mathrm{~mm}]$ & 39.013 & $\mathrm{~d}_{6}[\mathrm{~mm}]$ & 39.015 \\
\hline \multicolumn{6}{|c|}{ Cylinder no.3 } \\
\hline $\mathrm{d}_{1}[\mathrm{~mm}]$ & 39.019 & $\mathrm{~d}_{2}[\mathrm{~mm}]$ & 39.018 & $\mathrm{~d}_{3}[\mathrm{~mm}]$ & 39.020 \\
\hline $\mathrm{d}_{4}[\mathrm{~mm}]$ & 39.021 & $\mathrm{~d}_{5}[\mathrm{~mm}]$ & 39.017 & $\mathrm{~d}_{6}[\mathrm{~mm}]$ & 39.019 \\
\hline
\end{tabular}

Table 3. Differences in diameter's for nominal and worn cylinder

\begin{tabular}{|c|c|c|c|c|c|}
\cline { 2 - 6 } \multicolumn{2}{c|}{} & \multicolumn{4}{c|}{ Differences } \\
\hline \multicolumn{2}{|c|}{ Cylinder no. 1 } & \multicolumn{2}{c|}{ Cylinder no. 2} & \multicolumn{2}{c|}{ Cylinder no. 3 } \\
\hline $\mathrm{d}_{1}[\mathrm{~mm}]$ & $\mathrm{d}_{4}[\mathrm{~mm}]$ & $\mathrm{d}_{1}[\mathrm{~mm}]$ & $\mathrm{d}_{4}[\mathrm{~mm}]$ & $\mathrm{d}_{1}[\mathrm{~mm}]$ & $\mathrm{d}_{4}[\mathrm{~mm}]$ \\
\hline 39.011 & 39.010 & 0.003 & 0.005 & 0.009 & 0.012 \\
\hline $\mathrm{d}_{2}[\mathrm{~mm}]$ & $\mathrm{d}_{5}[\mathrm{~mm}]$ & $\mathrm{d}_{2}[\mathrm{~mm}]$ & $\mathrm{d}_{5}[\mathrm{~mm}]$ & $\mathrm{d}_{2}[\mathrm{~mm}]$ & $\mathrm{d}_{5}[\mathrm{~mm}]$ \\
\hline 39.011 & 39.011 & 0.001 & 0.002 & 0.006 & 0.008 \\
\hline $\mathrm{d}_{3}[\mathrm{~mm}]$ & $\mathrm{d}_{6}[\mathrm{~mm}]$ & $\mathrm{d}_{3}[\mathrm{~mm}]$ & $\mathrm{d}_{6}[\mathrm{~mm}]$ & $\mathrm{d}_{3}[\mathrm{~mm}]$ & $\mathrm{d}_{6}[\mathrm{~mm}]$ \\
\hline 39.010 & 39.010 & 0.002 & 0.004 & 0.009 & 0.010 \\
\hline
\end{tabular}

These results (Table 2) were presented in Fig. 8. The scope of achieved measurements were from $39.010 \mathrm{~mm}$ up to $39.021 \mathrm{~mm}$. Calculated standard error for diameter mean estimation was less than $0.5 \%$.

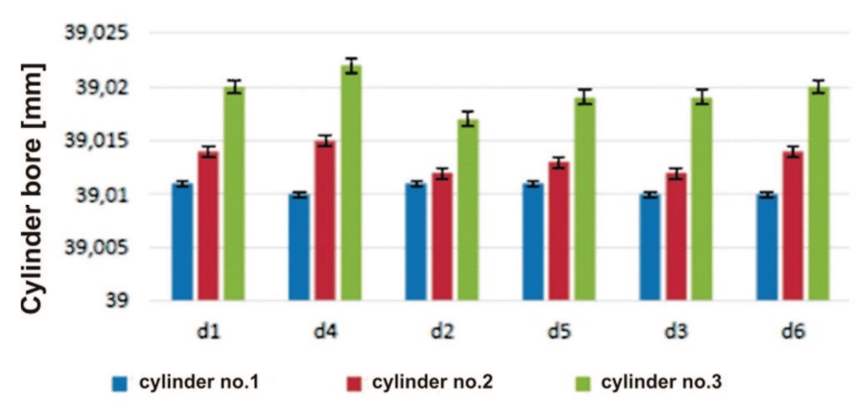

Fig. 8. Results of cylinder diameters measurements (arithmetic mean)

The measurements results presented in figure 8 let us state that the biggest cylinder wear was observed about TDC piston's position for both type of cylinder (no. 2 and 3 ). The lower wear of cylinders was observed close to BDC piston position. Significant impact of oil grade on cylinder wear intensity was observed during conducting an experiment. Lubrication of cylinder wall by worn engine oil results in increase of cylinder wear.

Another parts of our research were connected with measurement of cylinder's profile. The measurement were conducted by corner type profile meter HOMMEL TESTER T8000 made by HOMMELWERKE. This measurement stand was equipped by PC system, which allowed to make measurements of chosen profile indicators. This measurement system were based on Turbo Roughness computer application. It provided to achieve value the all normalized roughness parameters (R), undulations (W) and unfiltered parameters $(\mathrm{P})$ agree with ISO, DIN and JIS standards.

Marking of cylinder were the same like during wear measurements. For all cylinders a length of measurement were $4.8 \mathrm{~mm}$ and was located close to the medium of stroke. The results of profile measurements were presented in Table 4. Receive profiles of cylinder wall were presented in Fig. 9-11.

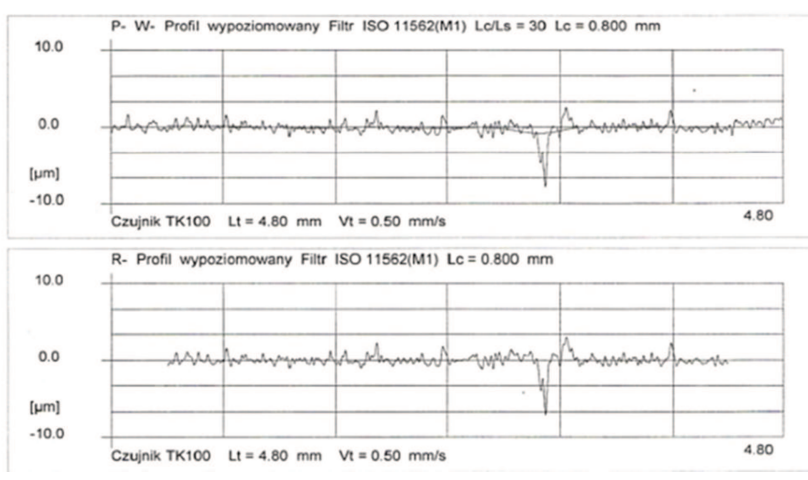

Fig. 9. Cylinder no 1 - wall's profile

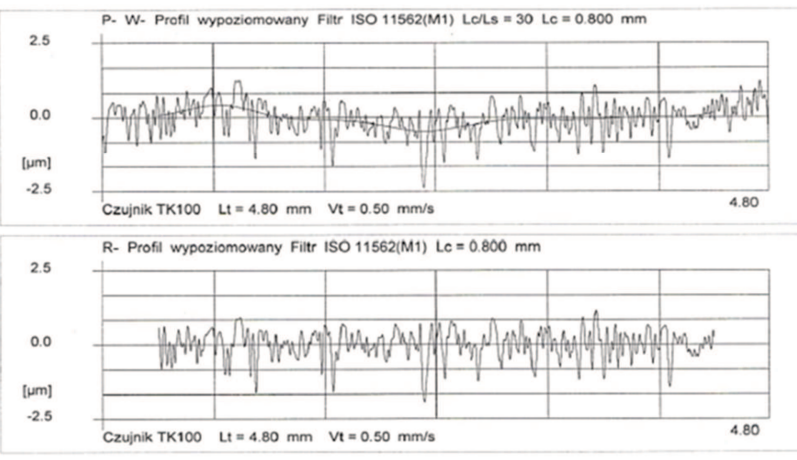

Fig.10. Cylinder no. 2 - wall's profile

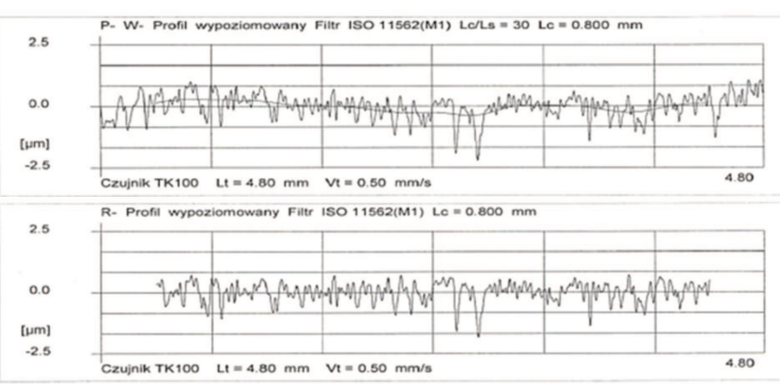

Fig.11. Cylinder no. 3 - wall's profile

Table 4. Results of measurements of cylinder wall roughness

\begin{tabular}{|l|c|c|c|}
\hline & Cylinder no. 1 & Cylinder no. 2 & Cylinder no. 3 \\
\hline Ra $[\mu \mathrm{m}]$ & 0.49 & 0.36 & 0.3 \\
\hline Rq $[\mu \mathrm{m}]$ & 0.79 & 0.47 & 0.39 \\
\hline Rz $[\mu \mathrm{m}]$ & 4.29 & 2.39 & 1.89 \\
\hline Rt $[\mu \mathrm{m}]$ & 10.02 & 3.06 & 2.55 \\
\hline Pt $[\mu \mathrm{m}]$ & 10.48 & 3.64 & 3.26 \\
\hline Wt $[\mu \mathrm{m}]$ & 1.07 & 0.89 & 0.69 \\
\hline
\end{tabular}

The results of profile parameters measurements let us state that reaching of TPC parts have an impact on decrease in roughness values. Third cylinder was characterized by the lowest value $R_{a}, R_{q}, R_{z}, R_{t}$ which worked with worn engine oil. In this case the most intensive dry friction were observed. The effect of reaching process was observed for 
the oil too. It was confirmed by decrease in Ra value. Decrease in roughness parameters were connected with cylinder surface smoothing and still left the superfinish rifts. It was presented in Fig. 9.

The biggest differences were observed for Rt parameter. This situation is caused by cooperation of cylinder wall and piston rings. It confirms that reaching process have significant impact on surface smoothing. Moreover, the superfinish of cylinder wall enhance this process.

\section{Summary}

On the basis of presented researches connected with cylinder wall wearing and roughness parameters for engine worked with the new and worn engine oil let us state that:
1. The oil grade and quality have a significant impact on cylinder wall wearing during engine starting, where the biggest wear was observed for cylinder which worked with worn oil.

2. During the experiment was observed similar character of cylinder wear process like it goes during normal engine work.

3. The oil quality have significant impact on friction's wearing what results in cylinder smoothing.

4. The biggest wear of cylinder wall was for the plane which is perpendicular to crankshaft axis.

5. Conducted research confirms that intensity of cylinder wear is caused by starting process, especially during cold start - what reflects in roughness decrease.

\section{Nomenclature}

TPC piston - cylinder - piston ring system

BDC Buttom dead center

TDC Upper dead center

\section{Literatura}

[1] BERNHARDT, M., DOBRZYŃSKI, S., LOTH, E. Silniki samochodowe. WKE, 1988, 489-516.

[2] BŁAŻEJ, A. Poradnik serwisowy - Vademecum stosowania olejów silnikowych, Instalator Polski. 2013, 14-25.

[3] DROŹDZIEL, P. Wybrane zagadnienia samochodowego silnika o zapłonie samoczynnym. Polskie NaukowoTechniczne Towarzystwo Eksploatacyjne. 2007.

[4] DROŹDZIEL, P. Widmo rozruchu silnika o zapłonie samoczynnym jako kryterium oceny warunków użytkowania samochodu. Polskie Naukowo-Techniczne Towarzystwo Eksploatacyjne. 2009.
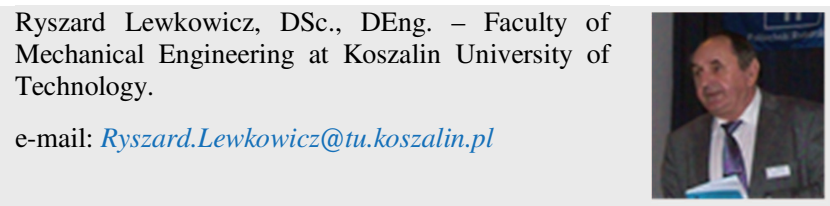

Ryszard Ściegienka, DSc., DEng. - Faculty of Mechanical Engineering at Koszalin University of Technology.

e-mail:Ryszard.Sciegienka@tu.koszalin.pl
[5] GOŁĄBEK, S., JANECKI, J. Zużycie części i zespołów pojazdów samochodowych. WKiŁ. Warszawa 1979, 163-171.

[6] ISKRA, A. Rozkład filmu olejowego na gładzi cylindrowej silnika tłokowego. Wydawnictwo Politechniki Poznańskiej. Poznań 1987.

[7] KAŹMIERCZAK, A. Tarcie w ruchu posuwisto-zwrotnym zespołu tłok-pierścienie-cylinder. Oficyna Wydawnicza Politechniki Wroctawskiej. 2005, 23-52.

[8] WŁODARSKI, J.K. Tłokowe silniki spalinowe - procesy trybologiczne, WKit. 1982.

[9] WRÓBLEWSKI, P. Ważne mikrometry. AutoEXPERT 2015, 5, 30-31.

[10] www.49ccscoot.com/manuals/139QM_Engine_Manual.pdf

[11] www.auto-met.com/fowler/pdf/387.pdf

Piotr Piątkowski, DSc., DEng. - Faculty of Mechanical Engineering at Koszalin University of Technology.

e-mail: Piotr.Piatkowski@tu.koszalin.pl

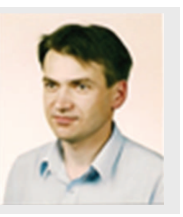

Błażej Szymaniuk, MEng. - Mechanical Engineering

at Koszalin University of Technology.

e-mail: Blazej.Szymaniuk@gmail.com 